\title{
Icons of Sacred Matter: the Interpretation of Dutch Golden Age Painting in the Light of Protestant Hierotopy
}

\author{
Andrew Simsky \\ Research Center for Eastern Christian Culture \\ Moscow, Russia \\ E-mail: andrew_simsky@mail.ru
}

\begin{abstract}
This paper employs the concept of Protestant Hierotopy to explore the spiritual roots of Dutch Golden Age Painting. Hierotopic methodology focuses on the creation of sacred spaces as a form of human creativity. Though the Reformation may have done away with ecclesiastical sacred spaces, it introduced a new kind of hierotopy in their place: a sacralization of the whole of Creation, with a focus on human environments. Protestant admiration for nature was imbued with religious feelings, while cleanliness and domesticity came to be seen as closely akin to holiness. In this paper I interpret Dutch Golden Age Painting as an iconography of this new form of sacrality. I argue that what we find in this art ought to be understood, not as a purely descriptive, objective realism conceived for its own sake, but rather as a passionate or even sacred naturalism motivated by admiration for God's marvelous creation and enhanced by a Protestant sense of coworking with the Creator.
\end{abstract}

Keywords-Protestantism; Dutch Reformation; Calvinism; Dutch Golden Age Painting; hierotopy; sacred space; pantheism; iconology; Baconian philosophy; Spinozist philosophy; neostoicism

\section{INTRODUCTION}

Although Dutch art of the 17th century has been studied inside and out, discussions focusing on the interpretation of its passionate naturalism are still ongoing [1]. This artful catalogue of the objects and materials that it took as subjects is a delight for the eyes: cows, flowers, clocks, even breakfast leftovers - anything and everything seemed to be worthy of astute attention and meticulous depiction. It may seem strange that this pictorial opulence blossomed in the arid soil of the rational, iconoclastic dogmatism of the Reformed Church, but this is so only at first sight. Although the Reformation did not promote art directly, it helped to create an atmosphere in which this particular type of art was able to flourish. While Calvinism ardently denounced devotional artwork in churches, at the same time, it explicitly encouraged its devotees to turn their attention to the beautiful book of Divine Creation, i.e., to the visible world. Even if Dutch artists, art patrons and intellectuals belonged to different denominations, they occupied a common ecumenical platform based on Christian values and a re-interpreted heritage of the Renaissance. The admiration of God's Creation served as a universal foundation of this platform. Aesthetics merged with religion into a distinct worldview characterized by the elevation, even the sacralization, of the material world. This worldview was the source of a broad cultural stream, which has been conceptualized in recent research as Protestant hierotopy [2][3].This paper opens with a brief introduction to the latter concept and then moves on to a more detailed discussion of its constituent aesthetic principles, in the bosom of which the artistic language of Dutch art was born.

\section{HiERotopy in Protestant CULTURE}

Hierotopy is concerned with the construction of sacred spaces. Originally introduced by Alexei Lidov in his Byzantine research [4], it initially focused on churches, relics and icons. Later on, its scope was broadened to include sacred landscapes and holy cities, as well as the sacralization of living spaces. Hierotopic creativity often takes concrete material forms, such as the construction of churches or the design of iconographic programs, but it also encompasses the purely mental creation of meaning. Various ambiences can reveal their sacred potentials through the simple renaming and rethinking of existing things. For example, a veritable Holy Land was re-created near the Istra New Jerusalem monastery - a famous Russian hierotopic project of the 17th century - merely by rechristening local hills, streams, and villages with Evangelical names. Protestant Hierotopy too consists predominantly in mental, as opposed to material, 'engineering' drawing upon the radical re-interpretation of matter and materiality brought about by the Reformation.

According to the Medieval worldview, the material world suffered the consequences of Original Sin and was ruled by the "prince of this world", while the sources of protective and salvific sacrality were to be found in churches and monasteries. The Reformation abolished ecclesiastical holiness, but also dramatically reduced the devil's powers, leaving at his disposal only instruments of moral seduction [5]. God's Grace, once evicted from churches, gushed out into the world and blessed all of Creation, which was henceforth seen to stand under God's omniscient and omnipotent control. The church sacraments 
lost their sacredness, but the natural and the ordinary acquired a new aura of holiness. Family homes became new loci sancta, where cleanliness and homeliness formed a new type of grace with a clear mission to bless and elevate daily life. The family dinner came to replace Holy Communion, while the cult of mother and child replaced that of the Madonna, imbuing maternity as such with an aura of sacrality. The Divine Light lit up Nature and shone through matter.

Thus, Protestant hierotopy emerged as a hierotopy of holy cleanliness, blessed domesticity, Biblical patriotism [6] and the iconization of nature. Protestant hierotopy is a unified cultural paradigm, which has at its core the sacralization of the material world, and which manifests itself on a number of different levels of spatial reality, such as that of the universe, the country, and the home. Whereas original Byzantine hierotopy was concerned with the construction of sacred spaces in designated places, Protestant hierotopy involved the construction of sacred meanings for the entire human cosmos ${ }^{1}$. As we shall see, Dutch Golden Age paintings can be seen as icons representing these sacred meanings, which, in this unique case, were epitomized in the appearance of things and their very materiality. Such iconicity was, in fact, one of the basic tenets of Protestantism.

\section{THE VISIBLE WORLD AS ICON}

With Protestantism, the word lost its former sacredness. After the Bible was translated into vernacular languages, its text was no longer sacred - only the content remained divinely inspired. A similar transformation occurred with the texts of liturgies and prayers. While the language was losing its divine aspect and becoming a mere instrument of social communication, images were rediscovered as a universal language, intimately related to the true nature of things. Illustrated Bibles published by Protestants far surpassed their Catholic counterparts in the richness of their illustrations [8].

The Calvinist confession of faith stated from its outset the religious significance of the visible world and formulated this in clearly aesthetic terms: "We know God by two means: First, by the creation, preservation and government of the universe, since that universe is before our eyes like a beautiful book in which all creatures, great and small, are as letters ... Second, God makes himself known to us more clearly by His holy and divine Word ...."[9]. While vehemently censuring any veneration of man-made icons, Calvinism called to view the entire visible world as the true icon of God fashioned for us by God Himself. The living presence of God was sensed behind the visible surface of things. He could not be depicted, nor imagined, but it was possible to see Him, even touch Him, in every leaf or blade of grass. Though He was unknowable and ineffable, He was close at hand. The Calvinist worldview thus gravitated towards pantheism.

\footnotetext{
It is not by accident that one finds the constructivist mindset at work in hierotopy [7].
}

Although Calvin did not write much about art, he systematically and explicitly called upon his followers to view the world aesthetically [10]. He often spoke of vision as the best witness of Faith, even more convincing than rational reasoning. Indeed, vision captured everything at once and directly evoked delightful admiration - a true alpha and omega of Faith and heart-felt evidence of the existence of God, to which nature itself offered shining, visible proof. Calvinism thus favored direct observation to scholastic speculation. Both nature and the Bible were best known by the heart.

In the $17^{\text {th }}$ century, religion and science still walked together hand-in-hand. The admiration for God's power and wisdom as manifested in His Marvelous Creation inspired scientific research, which came to be seen as a mode of worship. Through the study of nature, scientists were able to better appreciate the wisdom of God's design and were able to expertly proclaim the greatness of the Creator ${ }^{2}$. Inasmuch as the natural sciences were primarily observational, nature, as an object of scientific study, was contemplated as an icon of God's creation. Academic journals of the 17th century featured far more engravings than formulas. Owing to the telescope and the microscope, the art of seeing shifted to the cutting edge of scientific cognition. Seeing and depicting were equivalent to knowing - hence, little surprise that painting too came to be defined as a science of the visible world [13].

\section{The Divine SCHILDERACTIGHEYT OF BEING}

In the 17th century, the admiration for nature came to function not only as a scientific and religious principle, but also as an aesthetic one. Calvinist aesthetics were inspired in large part by Genesis, where creatures were directly appraised by the Creator himself: "And God said that it was good”. What was good for God was assumed to be good for man as well. The classical ideal of beauty thus gave way to aesthetics of the picturesque (schilderachtig) [14]. Everything in existence that was visible to the eye was seen as potentially picturesque - the issue was in how it was depicted. An ugly dwarf, a spider, a rude peasant, or even a urine sample in a glass, examined by a doctor, had the potential of being rendered picturesque. Of course, the precision of the representation was not all that was at stake. In full accord with the broader paradigm of the Baroque, the aesthetics of the picturesque both implied and required a direct emotional response. The representation of nature in painting was expected not just to be authentic, but impressively authentic. It had to evince admiration worthy of the subject.

The Reformation did away not only with the ecclesiastical hierarchy, but also with the celestial one. God came to be understood not just as the supreme designer, but also as a maker of things. He was involved in creation in the most direct manner, occupying himself with each individual stone, plant, or animal. Hence no two leaves on a tree were perfectly identical, nor any two drops of rain. His power and

\footnotetext{
2 We refer here, in particular, to so-called 'natural theology' or 'physico-theology' [11], [12].
} 
His glory were revealed in the infinite richness of Creation and in its unabating variability. Indeed, the perfection of God was manifested in this variability, and the aim of art was to represent it. The individuality of things may have been accidental, but this very fortuity was divine and was therefore also the necessary focus of the artist's interest.

A renewed stoicism came to serve as the philosophical foundation of this attitude toward nature. The ancient stoics had held that God penetrated the world in the form of pneuma, a universal animating force and a bearer of information. The pneuma was understood to contain characteristics of all individual things and even provided for them an analogue of a soul [15]. Neo-stoicism, similarly, came to underpin the fundamental diversity of the visible world and the value of each individual existence.

The pantheistic spirit of the era found its most consistent expression in the teaching of Spinoza, which brought God as close as possible to nature. As God formed nature in His own image, the study of the visible world was at the same time the study of God. And as God was perfect by definition, the visible world was seen to be equally perfect, and everything in God's creation was worthy of attention.

The imitation of nature as it was thus came to take precedence over aspiring towards the classical ideal of beauty. Beginning artists were advised not to go to Rome. Indeed, was it not simpler to look around and enjoy the inexhaustible richness of the visible world? There was nothing ugly in nature. "The most disgusting and contemptuous things, if they are natural, must be regarded with admiration... Faithfulness to nature makes ugly things beautiful, while their faithful reproduction deserves the same kind of praise as the most exquisite product of art" [16].

The metaphor of the mirror prominently featured in the contemporary theory of art (a tradition that was carried on by S. Alpers [17]). The reflection in a mirror was true and false at the same time. The visible nature reflected God, as if in a mirror, but it was still perishable. The art of painting may have truly reflected nature, even if it was based on artful deception, but this deception was in both cases commendable and even deserving of admiration. A good painting was expected to generate the illusion of real presence as if what one saw were not a depiction, but the thing itself [18]. It did not merely allow one to see, but also to experience a whole range of accompanying emotions and sensations: drops of water had to seem wet, velvet had to feel soft, and a human face had to look alive. As such, the response to art was often described in the same terms as amorous passion, with frequent use of such words as "admiration" and "delight". Even if art was based on illusion, it aroused real emotions.

\section{FlOWERS AS ICONS OF DIVINE CREATION}

Art was frequently compared to poetry. Like poetry, it depicted nature, but it represented the feelings evoked thereby, in this case the admiration of the Divine Creation. The authenticity of individual flowers was thought to be far more important than the realism of the arrangement as a whole. Compositions were arranged on a panel or a canvas and, as a rule, were expressly fantastic. Trade primers recommended cutting the contours of flowers out of carton and working out the composition with the use of such mockups [19][20]. Just to give one example, the visible flatness of the "Flowers in a stone niche" by Bosshaert in "Fig. 1" is clearly due to the use of such a technique: while the flowers stand densely together, they never block each other out. The contours of flowers could be copied by tracing them from botanical compendia. The primary focus, however, was in their naturalistic coloring. When finished, flowers were covered with spots of light and populated with life. Techniques such as these bear similarities with the use of templates in the icon-making industry, which flourished in Eastern Christendom around the same time.

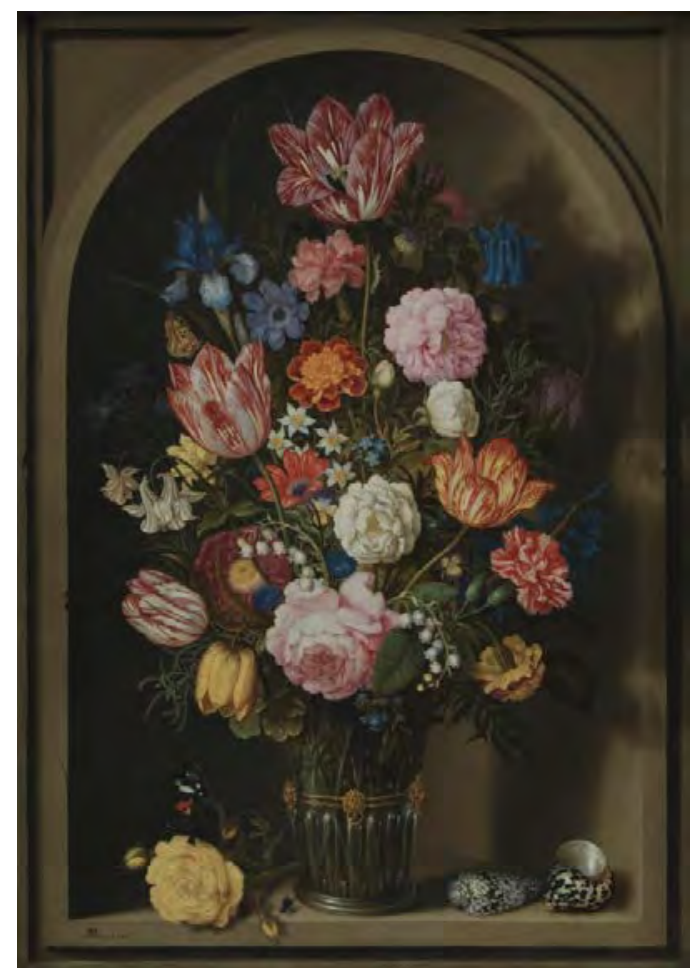

Fig. 1. Ambrosius Bosschaert the elder, bouquet of flowers in a stone niche, 1618, National Gallery of Denmark, Copenhagen.

These flower arrangements are not 'realistic' in a usual sense of the term and provoke other feelings than the more properly realistic bouquets of the $19^{\text {th }}$ century. Van Gogh, for example, is more realistic than De Heem in "Fig. 2" because he worked with real flowers in front of him. De Heem, for his part, did not require a real bouquet as a model. His task was not to depict nature as it really was, but to extol the incomparable magnificence of God's Creation. The purpose of his meticulous attention to detail was not to faithfully reproduce real flowers, but to impress the viewer by creating a sense of the real presence of a non-existent but utterly splendid hyper-bouquet. And it was clearly not just a question of the flowers but rather of a hymn to nature as a whole: no fewer than nine animals can be found in his bouquet, not counting the ants. Exotic and expensive flowers were painted most frequently, particularly so-called 'tiger tulips', a kind of striped tulips. Their exotic coloration 
was in fact caused by a rare viral infection. With such a bouquet on his wall, a middle-class city-dweller possessed something well beyond his reach. Familiar silhouettes of tiger tulips decorated just about everything, from ebony cabinets to ceramic tiles. Nature was thus extolled by depicting its most unique, valuable and expensive representatives.

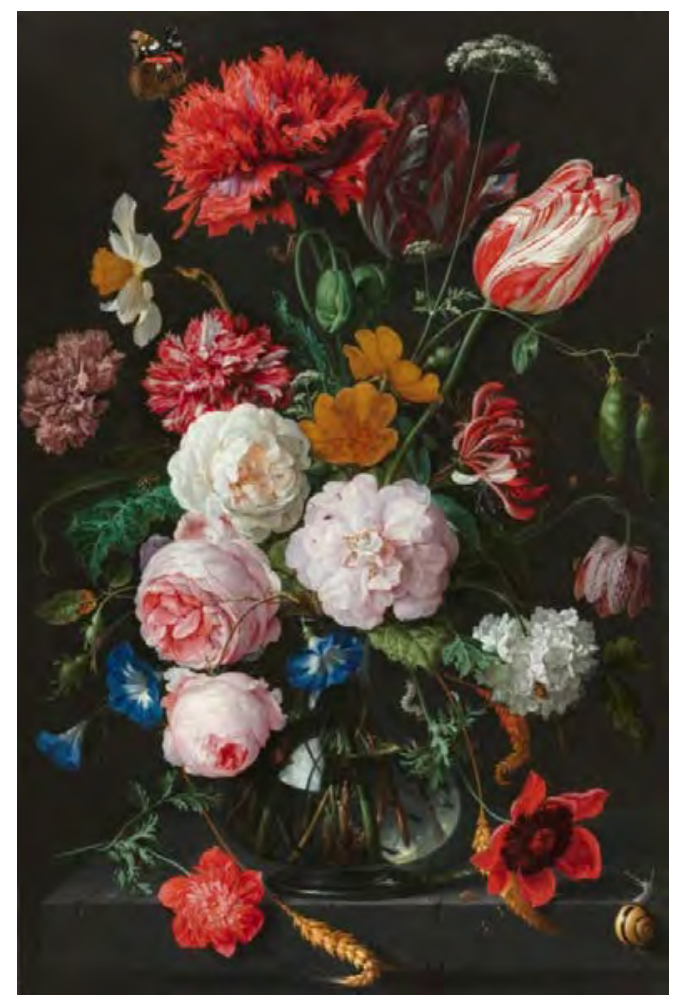

Fig. 2. Jan Davidsz. De Heem, Still life with flowers in a glass vase, between 1650 and 1683, Rijksmuseum, Amsterdam.

The meaning that flowers bore was self-evident, with emblem books unanimously associating them with life, joy, fertility, success and wealth. Such symbolism was archetypical and self-explanatory. In today's art-historical literature it is not uncommon to come across the opinion that cut flowers in vases symbolized the temporal and ephemeral character of earthly being. But to accentuate their ephemeral character, it would be more logical to depict fading flowers, which was never done. Indeed, flowers were always eternalized at the peak of their blossom and vitality, as if intentionally extracted from the merciless flow of time and thus rendered imperishable.

Clocks appeared frequently in floral arrangements, revealing an obvious link with physico-theology in "Fig. 3". With their complex mechanics, clocks were a commonplace metaphor for the rationally designed universe. They pointed to the systemic complexity and purposeful organization of nature and were depicted most often with their internal mechanisms exposed, demonstrating their sophisticated inner workings. Being on the cutting edge of technology at the time, they had a way of 'rhyming' with flowers in their various shapes and sizes, thus emphasizing how the products of human hands both imitate and add to the marvels of God's creation.

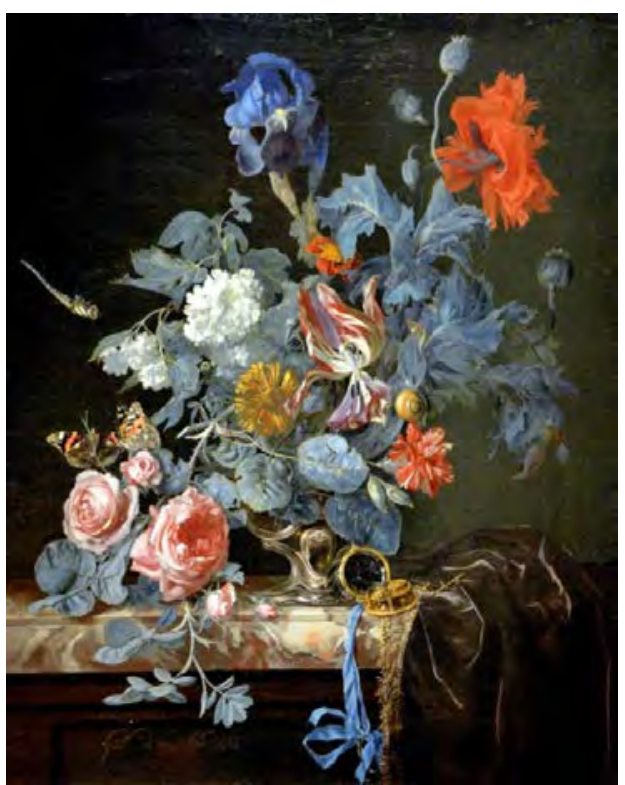

Fig. 3. Willem van Aelst. Flowers in silver vase, 1663, Legion of Honor, Fine Arts Museums of San-Francisco.

\section{ON THE SURFACE OF THINGS}

Inasmuch as visibility featured as a key attribute of matter, the latter was strongly associated with surfaces. Surfaces represented things and, in a sense, were the things themselves. Peeking deep into matter would only expose new surfaces. By looking at the surface of woven fabric through a magnifying glass, one could discover the surfaces of the threads themselves ${ }^{3}$. The fascination with matter thus entailed a fascination with surfaces, which came to acquire a fractal dimension. The motif of a heavily folded carpet was extremely popular. Persian rugs, which were usually employed in this capacity, were both impressive and absurd when placed on dining tables, and yet this is where they often appeared. The authentic rendering of textures in paintings was of utmost importance. The softness of velvet was different from the softness of silk and silver bore a shine that differed from that of steel. The texture of materials was seen as a stamp which God used to brand his creatures [21].

The exaltation of matter and materials was coupled with the assertion of the individuality of things and the value of their independent being. In "Fig. 4" each object is characterized in its own particular way and stands, as it were, on its own pedestal. An artificially contrived sense of the whole, which was to become so important for masters of later periods, was absent from Calvinist-style art. In "Fig. 4", objects are united only by the fact of their being placed together. Each material was created by God separately and was forged by intelligent hands into an accomplished,

The Dutch word for 'matter' (stof) means both a philosophical notion and woven fabric. 
strongly-built and self-sufficient object, a thing with a character and life of its own. Not only in still lifes, but even in group portraits, one notices a lack of connection between the component elements, as we mentioned already with respect to flower arrangements. Rembrandt's "Night watch", for instance, offers an analogue of De Heem's bouquets, but is composed of people. Rembrandt's musketeers, excellent as they are by themselves, stay apart and barely seem to notice each other.

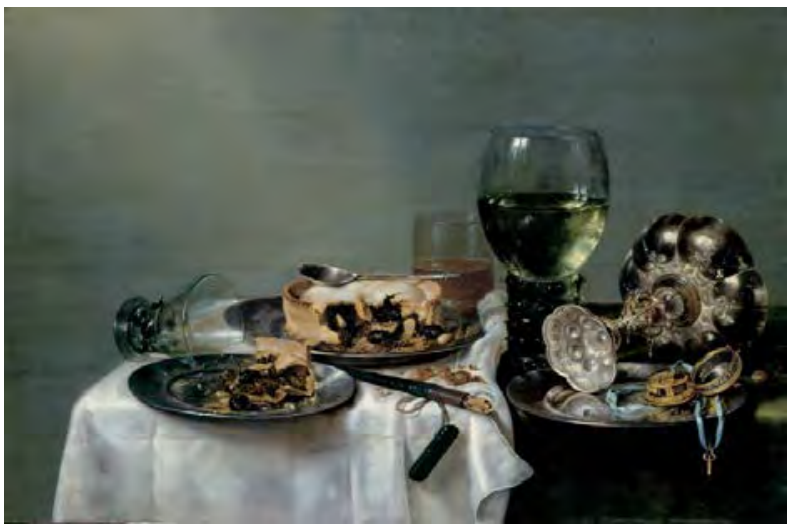

Fig. 4. Willem Claeszoon Heda. Breakfast table with blackberry Pie, 1631.Gemäldegalerie Alte Meister, Dresden.

\section{HOME, SACRED HOME}

Family became a bulwark and sacred core of Protestant culture. Luther's theological utopia of a sacred familial paradise in the Garden of Eden [22] is especially indicative of this new aura of sacrality surrounding family life, including everything from the rearing of children to sexual relations. In particular, it blessed the model of a small family consisting of a couple and their minor-aged children. Such 'family nests' (as Luther was wont to call them) came to be the norm in Dutch urban homes. In contrast to the Medieval model of a home-dormitory, this was a true family dwelling with its own sense of intimacy and its own atmosphere [23]. The cult of the home was also organically related to the revolution of cleanliness. Both were essential parts of Protestant Hierotopy, with its general spirit of the sacralization of the material.

A woman with a broom became an angel of this new religion of cleanliness and domesticity. In "Fig. 5", two godly activities are depicted: reading and cleaning. In a clean, brightly lit room, a maid sweeping the floor is shown in the foreground, making it easy to see which of the two activities is more important. An unrealistically luxurious marble floor elevates a modest dwelling to the level of a royal palace. What we see here, in essence, is the home of an artist represented as a temple of domesticity.

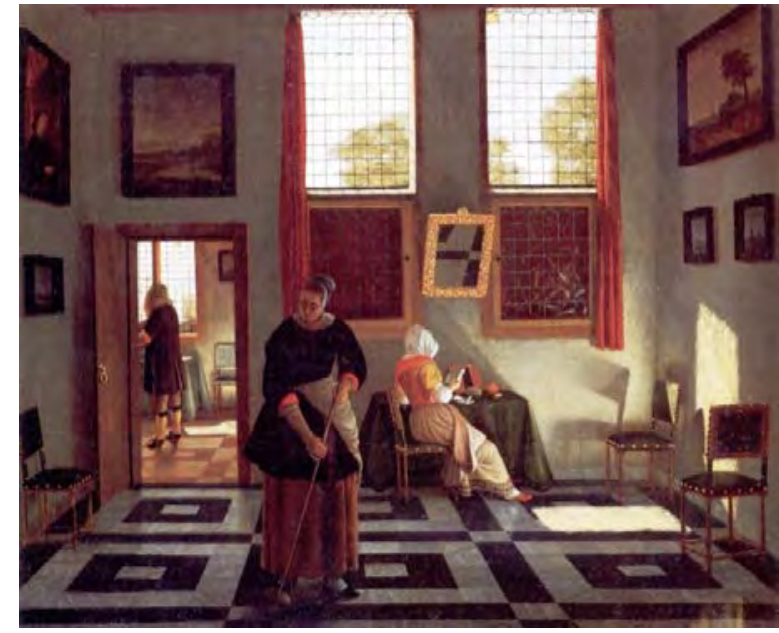

Fig. 5. Pieter Janssens Elinga, Interior with painter, reading lady and maid sweeping, 1668, Städel Museum, Frankfurt.

Marble floors, Persian rugs and copper chandeliers are so convincingly realistic in Dutch Golden Age interiors that generations of historians have axiomatically interpreted them as an authentic illustration of the middle-class lifestyle. Only recently has a special research [24] shown that these are no more realistic than all-season flower arrangements. Their purpose was not to show the domestic order in its modest reality, but rather to exalt it with the ennobling deception of passionate naturalism. The picturesque beauty of oriental rugs features in this context as a close relative to the tracery of tiger tulips. Both offered an enjoyment for the eyes. Both were fabulously expensive and exotic, and both were absent from the lives of the middle class. In short, both belonged to the iconography of sacred matter.

Brooms were also an important part of the new iconography, appearing in such contexts as would have been unthinkable in the art of other cultures or epochs. In "Fig. 6", a maid passes a letter (likely a love letter) to a lady playing a lute. And yet a broom stands front and center in the foreground. In "Fig. 7", we see a romantic couple. A broom is complemented by the presence of a bucket. Both relics of this new brand of sanctity are shown in the proscenium, a dark interior of a pantry. Such an intentional mix of romance and prose would be impossible in the art of both earlier and later epochs. But Dutch art is not aristocratic. The cleanliness and homeliness stand as high in its list of values as romantic feelings. In "Fig. 8" we see a lace maker at work. Why does she need a broom? We see that she has removed her street shoes. A custom of changing from street shoes to slippers was one of the significant achievements of the new cult of cleanliness ${ }^{4}$.

\footnotetext{
4 In many cultures, shoes must be removed before stepping into sacred or living space, see Fig. 8.
} 


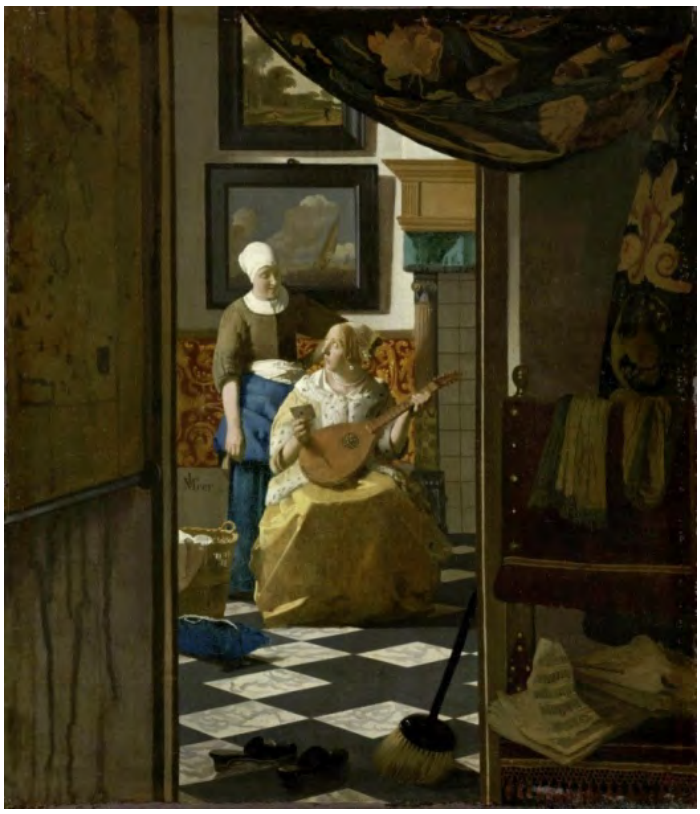

Fig. 6. Johannes Vermeer, Love letter, 1669-1670, Rijksmuseum, Amsterdam.

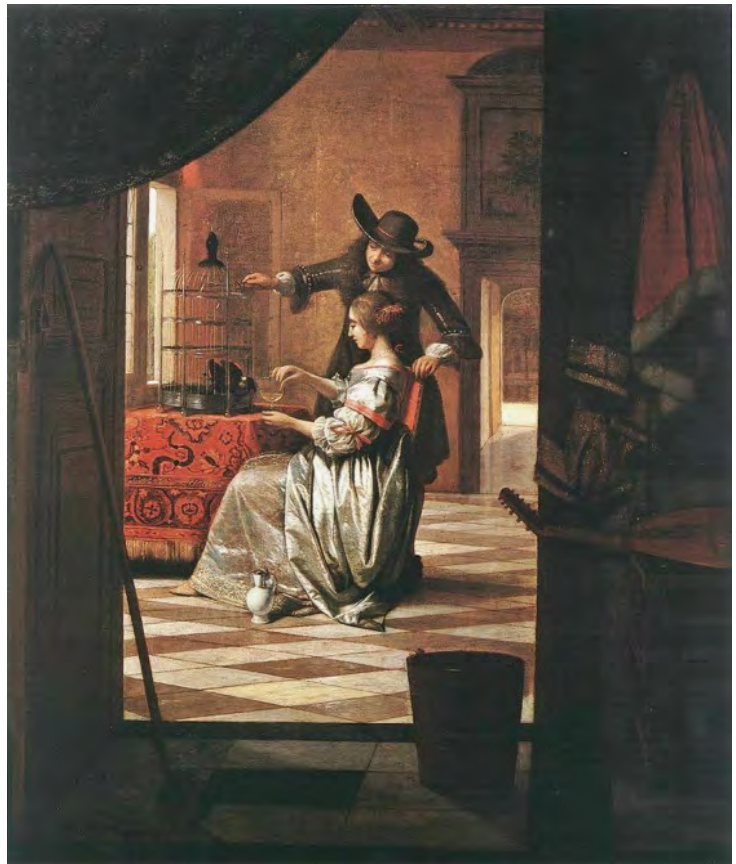

Fig. 7. Pieter de Hooch, Couple with parrot, 1675, Wallraf-RichartzMuseum, Cologne.

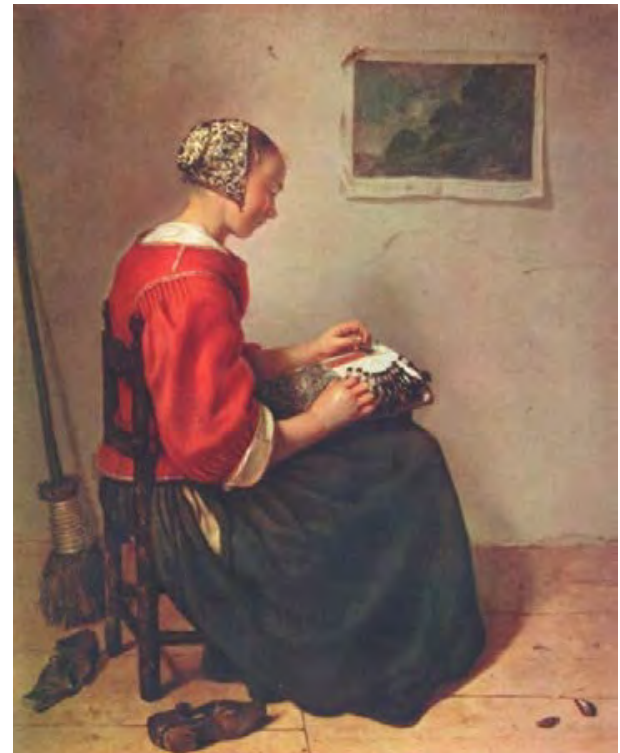

Fig. 8. Caspar Netscher, The Lace maker, 1662, Wallace Collection, London.

Another significant element of this new iconography of domesticity is the slipper, typically presented in the foreground. "Fig. 9" is a veritable icon of domesticity, with a broom and a pair of slippers occupying the center of the composition. It is worth noting than the author of this painting was an outstanding theoretician quoted earlier in this paper. In the unique atmosphere of this type of realism, a broom chimes with a candle, and slippers with a book. Another typical, iconic element of homeliness is the foot warmer, a wooden box with holes in its top, into which a ceramic bowl with glowing embers was inserted. Although in real life such warmers were needed only during winters, which are relatively short in Holland, in paintings, we see them all the time. They are straightforward and literal symbols of homely warmth and, in this capacity, are included independently of the season. Notice that, in brothel scenes, there are no slippers, no foot warmers and no brooms. Clients wear boots, hats and street clothing, as the status of brothels is equivalent to the status of the street. 


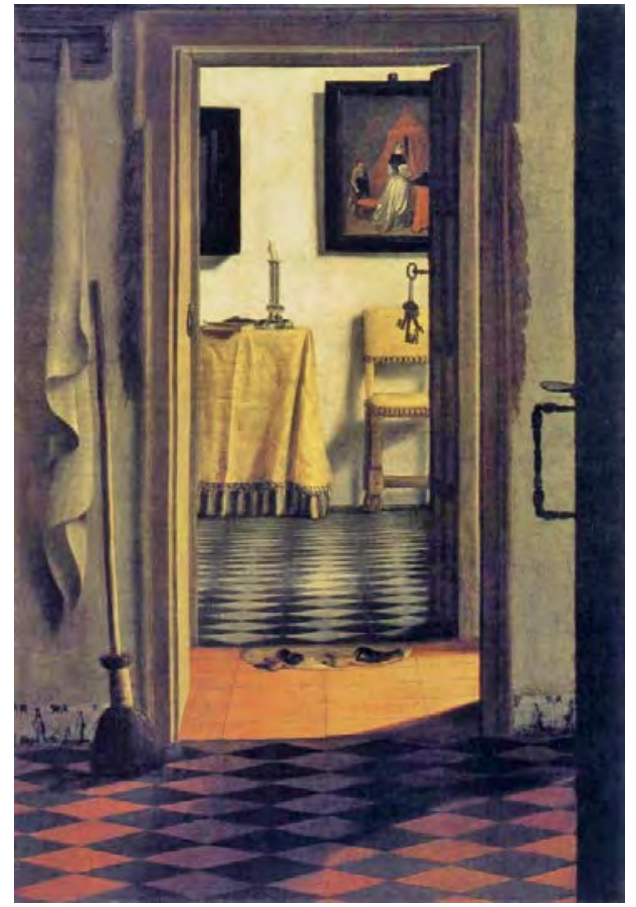

Fig. 9. Samuel van Hoogstraten. View of the interior (slippers). circa 1670, Louvre, Paris.

With the genesis of national identity, domesticity was elevated to the status of patriotism. The funerary monument to William the Silent shows the patriarch of Dutch independence on his deathbed dressed in an informal unbuttoned gown and in slippers in "Fig. 10". These slippers, carved out of marble, eternalize with the permanence and firmness characteristic of stone the cult of domesticity, sanctified with the blood of a new saint, martyred at the threshold of his own home.

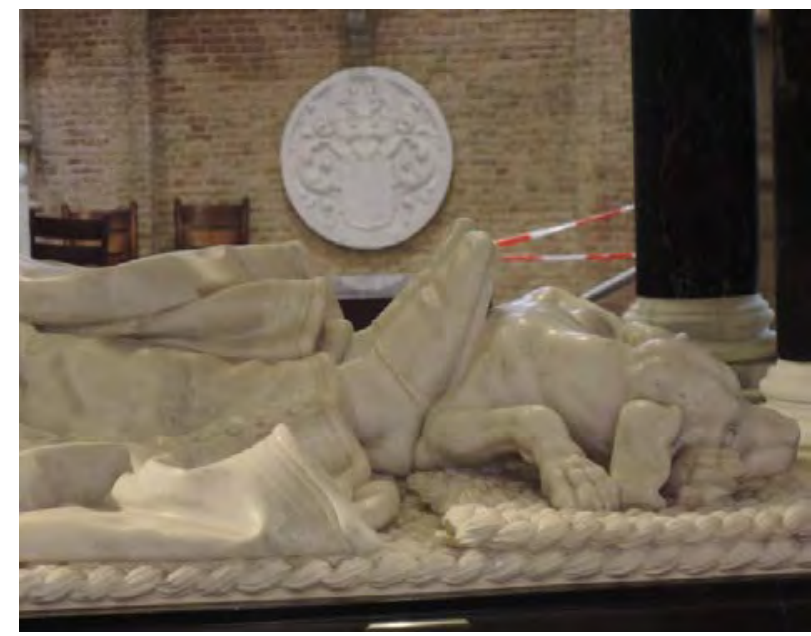

Fig. 10. The funerary monument to William the Silent in the New Church, Delft (fragment).

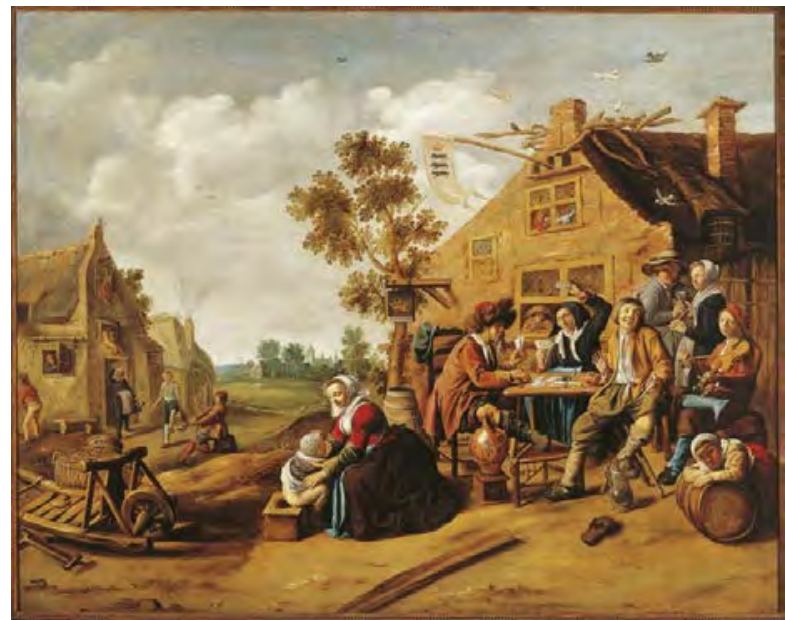

Fig. 11. Jan Miense Molenaer, Outside of 'De Kroon’ Inn, 1630, Frans Hals Museum, Haarlem

If the reader still has doubts about the significance of the iconographic aspect of Dutch realism, "Fig. 11" will drive the point home. At first sight it seems to be a genre composition in a trivial realistic key. An attentive viewer will notice, however, a completely different content. First, notice that the emblem of the tavern - three pigs - is offensive and, hence, completely unrealistic. Secondly, no reasonable mother would have a child use a wooden housetype potty in the middle of the village street. A solitary slipper and a foot warmer are out of place for the same reason. Finally, notice how a well-dressed lady with a child and peasants seated at the table, form two isolated groups and don't seem to notice each other.

The plot of this painting is the juxtaposition of two very different worlds: the world of decent urban life, with its spirit of holy homeliness, and the rough, ungodly life of peasantry. The arrogance typical of city dwellers with respect to uncultivated villagers has taken in Dutch culture, essentially urban, extreme forms. Until the end of the 17th century, peasants in paintings personified every conceivable form of vice in their most disgusting forms: they are typically seen drunk, eating greedily, laughing stupidly, courting their ladies (no less unattractive) in rude ways, relieving themselves in public and resolving their disputes with knife fights. Here we see them gambling, teaching children to smoke, emptying a night pot on a passerby and urinating at the wall. An urban lady in the center, idealized almost to the level of holiness, has nothing to do with this den of vices. Her presence demonstrates the contrast between culture and anti-culture, between the sacred and the profane. The den of vices seems to dominate the scene, with the lady and child hemmed in on all sides, the foot warmer being 'desecrated' by a bottle of wine placed on its top, and a slipper being overshadowed by rude boots. Let us again stress that a foot warmer and a slipper would be completely unnecessary in such an episode of rural life, especially in summer. Instead, they essentially belong to the cozy world of sacred urban homeliness represented by the lady and the child. 
It is quite common to search for coded moral messages in Dutch art, but this example clearly demonstrates that ethical points were asserted, if necessary, in quite a straightforward manner. Diverse spiegel-books filled with didactic allegorical engravings and very clear captions were published en masse. While allegoric language was an inheritance of the past, the gist it acquired in the new naturalistic art was all its own: the exaltation of God's creation and of His gifts to man, as well as man's godly effort to create for himself a sacred environment worthy of divine blessing.

\section{CONCLUSION}

This paper has explored the spiritual roots of Dutch fine art of the $17^{\text {th }}$ century in the light of Protestant Hierotopy, a distinct strain of Dutch culture that, at its core, consists in the exaltation of matter and materiality. I have argued that the naturalism of Dutch paintings was an expression of this distinct worldview, deeply rooted in Protestantism, and that these paintings can be interpreted as icons of exalted matter, God's admirable Creation and sacralized domesticity. The scope of the present discussion has been limited to flower arrangements and home interiors as representative examples, leaving a review of other genres for future publications (landscapes were touched in [25]).

\section{REFERENCES}

[1] Eric J. Sluijter. "Didactic and disguised meanings. Several Seventeenth-Century texts on Painting and Iconological Approach to Northern Dutch Paintings of This Period.” In: Art in History. History in Art. Studies in Seventeenth-Century Dutch Culture. Eds. D. Freedberg\& J. de Vries, Santa Monica, CA: the Getty Center, 1991, p. 175-207.

[2] A. Simsky. "Holy Water, the Reformation and Protestant Hierotopy.”In: Holy Water in the Hierotopy of the Christian World.Ed. A.Lidov, Moscow: “Theoria”, 2017, p. 685-724.

[3] A. Simsky. "Protestant Hierotopy in Dutch Golden Age Painting."

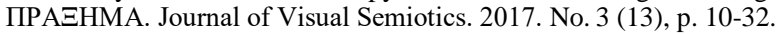

[4] A. Lidov, Hierotopy. Spatial Icons and Image-Paradigms in Byzantine Culture. Moscow: “Theoria”, pp. 352.

[5] N. Johnstone."The Protestant Devil: the Experience of Temptation in Early Modern England.” Journal of British studies, Vol. 43, April 2004, p. 173-205.

[6] S. Schama. The Embarrassment of the Riches. An Interpretation of Dutch Culture in the Golden Age. NY: Vintage Books, 1987, Ch. 2 "Patriotic Scripture", p. 51-125.

[7] A. Simsky. "Hierotopy as Principle and Instrument." ПРА $\Xi H М A$. Journal of Visual Semiotic, 2018. No. 2 (16), p. 70.

[8] Ph. Benedict. “Calvinism as a Culture.” In: Seeing Beyond the World. Visual Arts and the Calvinist Tradition. Ed. P. C. Finney. Cambridge/Grand Rapids: W. B. Eerdmans Pub., 1999, p.33.

[9] Confessio Belgica, art. 1.

[10] J. Calvin. Institutes of Christian Faith. Book 1. Ch. 5.

[11] M.Vassanyi. "Religious Awe at the Origin of Eighteenth-century Physico-theology." In: Philosophy Begins in Wonder. An Introduction to Early Modern Philosophy, Theology, and Science. Eds. M. F. Deckard \&P.Losonczi. Eugene, Pickwick Publications, p. $72-104$.

[12] A. Simsky, "Holy Water, the Reformation and Protestant Hierotopy," p. 704-707, 721 .
[13] S. Van Hoogstraeten. the Introduction to the Academy of Painting, or the Visible World in Dutch. Inleyding tot de hooge schoole der schilderkonst; anders de zichtbaere werelt, Rotterdam, 1678, p. 24.

[14] Th. Weststeijn. The Visible World. Samuel van Hoogstraten’s Art Theory and the Legitimation of painting in the Dutch Golden Age. Amsterdam Univ. Press, 2008, section “A Painterly Art”, p. 252-265, also pp. 88-91, 107.

[15] S. Sambursky Physics of the Stoics. Princeton Univ. Press, 1987, p. 7-11.

[16] S. Van Hoogstraeten, op. cit., p. 77.

[17] S. Alpers. The Art of Describing. Dutch Art in the Seventeenth Century. Univ. of Chicago Press, 1983.

[18] Th. Weststeijn, op. cit., p. 137.

[19] G. de Lairesse. 'Great Book of Painting' in Dutch, Groot schilderboek, Amsterdam, 1707, p. 367

[20] S. van Dorst Brueghel, 'Seghers and de Heem. The Techniques of Flower Painters from Seventeenth-Century’ Antwerp // Power Flower. Still lifes with Flowers from the Netherlands in Dutch. Seghers en de Heem. De techniek van bloemschilders uit het zeventiende-eeuwse Antwerpen.” In: Power Flower. Bloemstillevens in de Nederlanden. Antwerp: Rockox museum, 2015, p. 57.

[21] F. Bacon. Works in 14 vols, London, 1857-1864, vol. 4, p. 29.

[22] M. Luther. Creation. A Critical and Devotional Commentary on Genesis 1-2. Ichtus Pub., 2016, Kindle, Part.9. "Paradise”.

[23] W. Rybczynski. Home. A Short History of an Idea. Harrisonburg, VA: R. R. Donneley\& Sons Co. 1987, 256 p.

[24] C. W. Fock. 'Reality or Appearance. The Images of Dutch Interiors in the Seventeenth-Century Genre Painting' // Old Holland "Werkelijkheid of schijn. Het beeld van het Hollandse interieur in de zeventiende-eeuwse genreschilderkunst” In: Oud Holland, Vol. 112, No. 4, 1998, p. 187-246.

[25] A. Simsky. "Protestant Hierotopy in Dutch Golden Age Painting.” p. 28. 